INTERNATIONAL JOURNAL OF
ORGANIZATIONAL LEADERSHIP
ORGANIZATIONAL
IEADRSHIP

\title{
Linking Self-efficacy and Organizational Citizenship Behavior: A Moderated Mediation Model
}

\author{
Saif Ullah', Basharat Raza ${ }^{2 *}$, Wasif Ali ${ }^{3}$, Sana Amjad ${ }^{4}$, Atif Khan Jadoon ${ }^{5}$ \\ ${ }^{1}$ National College of Business Administration and Economics, Lahore, Pakistan \\ ${ }^{2} \mathrm{HOD}$, School of Business Administration, National College of Business Administration \& Economics, Lahore, \\ Pakistan \\ ${ }^{3}$ University of Calgary, Canada \\ ${ }^{4}$ Khawaja Fareed University of Engineering and Information Technology, Rahim Yar Khan, Pakistan \\ ${ }^{5}$ University of the Punjab, Lahore, Pakistan
}

Keywords:

Self-efficacy, Incivility,

Prosocial Motivation,

Organizational Citizenship

Behavior, Social Cognitive

Theory

Received

23 June 2021

Received in revised form

20 July 2021

Accepted

31 July 2021

*Correspondence:

basharat.hailians@gmail.com

\begin{abstract}
This study investigates the relationship between self-efficacy and Organization Citizenship Behavior (OCB), moderated by incivility and mediated by pro-social motivation. Selfefficacy is the employee's belief in him about his skills to perform tasks in different situations. The direct and indirect effects of self-efficacy of teachers towards their OCB through prosocial motivation have been observed in this study. For this purpose, data has been collected through questionnaires $(\mathrm{N}=301)$ using convenience sampling in three-time phases with two weeks gaps between each phase. SPSS 22.0 and Amos 22.0 were used along with Process by Hayes for moderated mediation analysis. The results indicate that self-efficacy leads to organizational citizenship behavior (OCB) and pro-social motivation, moderated by incivility and mediated by pro-social motivation. In a nutshell, this study demonstrates self-efficacy enhances pro-social motivation and OCB within academic settings with reference to Pakistan, advocating that if teachers are confident to perform a task, they can also demonstrate their extra-role behavior. The present study contributes to the literature by analyzing the novel framework within the Pakistan context. The mediating effect of prosocial motivation between teachers' self-efficacy and OCB has not been discussed in the prior studies. The implications, discussion, and conclusion are also discussed.
\end{abstract}

(C)CIKD Publishing

The inception of the concept of "self-efficacy" in the late $20^{\text {th }}$ century gave researchers a new direction to understand human behavior concerning organizational goals. In today's world, the 
concept of self-efficacy is found in its refined form and widely used in research and industry as one of the essential positive constructs to assess behaviors and capabilities of working personnel around the world. Thus, many researchers (Bandura, 1997; Goddard, Hoy, and Hoy, 2004; Robbins, 2005; Tschannen-Moran \& Hoy, 2001) inquire into the effects of self-efficacy over an individual's behavior, task performance, and employee effectiveness. In contrast, selfefficacy is the employee's belief in himself about his skills to perform tasks in different situations (Bandura, 1997). Furthermore, the idea of comprising self-efficacy created within psychological studies has been adjusted towards numerous settings and utilized in various organizations (Yeşilyurt, Ulaş, \& Akan, 2016).

Self-efficacy, which is generally, takes as a positive predictor of performance and productivity (Cherian \& Jacob, 2013) and further has a positive impact on OCB (Judge \& Bono, 2001; Judge et al., 1998; Ringgasa, 2017). Whereas, very few studies indicate a negative effect of self-efficacy with an individual's motivation (Vancouver \& Kendall, 2006) because people want to distinguish themselves and feel uncomfortable from helping others since they want to keep their self-image (Lin, Schaumberg, \& Reich, 2016). Previous studies focus on the impact of teacher efficiency on students' academic performance (Goldhaber, 2002). The indicator of teacher efficiency is also considered teachers' leadership skills by some previous studies (YorkBarr \& Duke, 2004). According to Oplatka (2009), the OCB behavior of teachers is considered an important contribution of teachers to the organizations. In the classroom, the OCB behaviors of teachers impact positively both within and outside the institution. The OCB behaviors performed by teachers positively impact both the performance of students and institutions and the sense of self-actualization (Oplatka, 2009). Some studies conclude the findings in the context of schools. Still, these findings cannot be generalized to college teachers because the context of schools and colleges is different in the sense of culture, level of students, nature of work, and task demands. On the other hand, the career path is also very different from school and college teachers (Paramasivam, 2015).

Just like self-efficacy, pro-social motivation (an intention to help others) also impacts OCB positively (Grant \& Mayer, 2009). Previous research findings suggested that improving an individual's self-efficacy may help motivate employees for better performance (Cherian \& Jacob, 2013). In addition, several other studies indicated the positive relationship between prosocial motivation and OCB (Abid, Sajjad, Elahi, Farooqi, \& Nisar, 2018; Lebel \& Patil, 2018). Moreover, the study of Bandura (1993) suggests that self-efficacy helps induce motivation and learning among teachers. Therefore, we assume that self-efficacy will also induce pro-social motivation. In short, self-efficacy brings positive energy, which will be helpful to induce motivation in a person to do a specific task. This specific task may include but is not limited to demonstrate a courteous attitude towards colleagues, supervisors, subordinates, or organization resulting in pro-social motivation. As self-efficacy and pro-social motivation bring positive results towards OCB, the relationship between self-efficacy and OCB through pro-social motivation has not been thoroughly discussed in earlier studies.

As we have discussed a couple of positive constructs early, including self-efficacy and prosocial motivation, this paper also highlights one of the negative constructs named incivility. Incivility is a negative behavior intended to harm others when mutual respect and professional norms are compromised (Andersson \& Pearson, 1999). Research shows the negative impact of incivility on working individuals in a particular workplace (Cortina, Magley, Williams, \& 
Langhout, 2001), diminishing workers' performance (Arasli, Hejraty Namin, \& Abubakar, 2018). Moreover, incivility also negatively impacts worker's self-efficacy (Riadi, Hendryadi, \& Tricahyadinata, 2019). Past research shows that workplace incivility lowers employees' intrinsic motivation by increasing their emotional exhaustion (Hur, Moon, \& Jun, 2016). Another study conducted by Alola, Avci, and Ozturen (2018) showed negative results of incivility over the turnover intention and job satisfaction in a relationship presenting selfefficacy as a mediator between supervisor's uncivil behaviors and employee's turnover intention and job satisfaction. As a negative construct, it means incivility will change or moderate the positive relationship of two or more variables by a noticeable margin. Therefore, we argue that incivility may moderate the understudied positive relationship between self-efficacy and prosocial motivation.

It is evident from the above-mentioned discussion that incivility hinders the performance of individuals; therefore, this study proposes a framework consisting of constructs like selfefficacy, prosocial motivation, $\mathrm{OCB}$, and incivility. It has been observed that various teachers show different levels of prosocial motivation and OCB in different organizations. This study aims to find out how incivility reshapes the teachers' prosocial motivation and OCB as in the academic organizations in Pakistan.

To the best of our knowledge, there is no study available with reference to Pakistan to investigate the direct and indirect relationship between teachers' self-efficacy and their OCB via prosocial motivation along with incivility as moderator. This study shall contribute valuable insights towards existing literature and practice. The aims of this paper are as follows: (a) to find out the relationship of teachers' self-efficacy with OCB and the indirect relationship of selfefficacy to OCB via pro-social motivation, and (b) to discover the moderating impact of incivility over the direct relationship of teacher-related self-efficacy with pro-social motivation.

\section{Literature Review}

\section{Self-efficacy and Organization Citizenship Behavior (OCB)}

Teacher self-efficacy defined by Guskey and Passaro (1994) as teachers' beliefs in their ability to attain the desired students' outcomes. It has a negative relationship with burnout and stress of teachers. Further, it is a strong predictor of higher students' motivation and academic achievement (Caprara et al., 2006; Ross, 1992; Schunk, 1991; Schwarzer \& Hallum, 2008; Wang, Hall, \& Rahimi, 2015). Bandura (1997) explained the positive impact of self-efficacy with the help of self-efficacy theory. This theory states that the people who have self-efficacy characteristics are determined in the face of hindrances and are more task-oriented. In the education field, self-efficacy means positive and effective behavior of teachers in the classroom. The teacher's effectiveness can be judged based on the behavior that may impact the organization's long-term continual progress and performance. OCB is a behavior that produces a positive workplace environment and brings long-term organizational effectiveness (Podsakoff, Ahearne, \& MacKenzie, 1997).

The OCBs behaviors are the extra-role behaviors instead of formal job descriptions of employees, which help to increase the organizational effectiveness. This construct has been studied in many fields, primarily in management and organizational behavior literature (Organ \& Ryan, 1995). In the educational context, this construct is more important because it is very problematic to define the role of a teacher in the institute. It is difficult for the administrator to 
manage and measure the OCBs behaviors of individuals because these behaviors are voluntary and cannot be defined under a formal job description. The antecedents of this voluntary behavior cannot be limited to organizational factors. Self-efficacy is one of the individual-level factors, which can motivate to accept responsibilities and extra-role behaviors (Bogler \& Somech, 2004).

Several studies reveal the positive impact of self-efficacy over OCB (Judge \& Bono, 2001; Judge et al., 1998). As far as teachers are concerned, Bogler and Somech's (2004) study showed self-efficacy is a strong predictor of OCB. Self-efficacy can be related in an academic context to teacher self-efficacy, principal self-efficacy, and student self-efficacy. According to Goddard et al. (2004), the self-efficacy of tutors can be tracked with teaching success. Furthermore, the judgment of the teacher's commitment toward students learning via teaching skills also reflects a teacher's self-efficacy (Tschannen-Moran \& Hoy, 2001). Zee, Koomen, Jellesma, Geerlings, and de Jong (2016) explore positive links between a teacher's self-efficacy with instructional support, class management, and expressive support.

Self-efficacy impacts an instructor's sense of achievement by reducing emotional fatigue. This effect can be seen over a stretched-out period (Brouwers \& Tomic, 2000) and aids a transformation of health-related behavior (Bandura, 1997). Furthermore, Lane, Lane, and Kyprianou's (2004) study, conducted in an academic setting, reveals that self-efficacy mediates the relationship between performance accomplishments and academic performance. Recently, the results shown by the study of Paramasivam (2015) indicated a strong self-efficacy impact over teachers' OCB. In contrast, the findings of the study conducted by Ringgasa (2017) confirm that self-efficacy directly and positively impacts OCB. In a nutshell, self-efficacy improves a person's performance due to the self-belief and confidence that he can do what he thinks, and this will also impact his intention to do good for others positively.

Furthermore, Asandimitra and Kautsar's (2019) study revealed that self-efficacy also influences the management behavior of female lecturers. Besides the direct role of teacherrelated self-efficacy over OCB, the indirect link of teachers' self-efficacy with OCB is also meaningful as self-efficacy varies with different organizational and environmental factors that may affect the intensity of self-efficacy (Nowakowska, Rasińska, \& Głowacka, 2016). Furthermore, Social Cognitive Theory (SCT) emerged from the works of Bandura (1993) embedded with the idea of self-efficacy. This theory explains the ability incarnate of an individual that he adjusts himself through a locus of control over certain actions and behaviors. Therefore, based on the above-discussed literature and cognitive theory, we assume that selfefficacy is positively linked with OCB.

\section{Pro-social Motivation as a Mediator}

Pro-social motivation is an aspiration of benefactors to benefit the beneficiaries (Grant et al., 2007). Pro-social motivation has been investigated in many fields like applied psychology, positive organizational studies, and organizational behavior (Grant \& Berg, 2012). According to Grant et al. (2007), it concerns the desire to impact individuals positively. In the study of Castanheira, Chambel, Lopes, and Oliveira-Cruz, (2016), pro-social motivation serves as a mediator between resources and work engagement, reflecting high work engagement due to increasing levels of pro-social motivation. In addition, pro-social motivation inspires individuals to frame their behavior to help colleagues (Arieli, Grant, \& Sagiv, 2014). Several studies reported a positive 
impact of pro-social motivation on OCB and performance (Grant \& Mayer, 2009; Grant \& Sumanth, 2009; Rioux \& Penner, 2001).

Furthermore, Lebel and Patil (2018) showed that employees who are prosocially motivated maintain their tendency to help others. So, when a person is prosocially motivated, he feels an upward swing of positive mood and long-lasting energy, which creates a worthy relationship with others (Abid et al., 2018), insisting that he shows his OCB towards other people. In short, self-efficacy brings positive energy, which will be helpful to induce motivation in a person to do a specific task. This specific task may include but is not limited to demonstrate a courteous attitude towards colleagues, supervisors, subordinates, or organization resulting in pro-social motivation. It means pro-social motivation is directly related to OCB. The higher the pro-social motivation is, the higher will be OCB and vice versa. While, teachers' self-efficacy drives motivation and promotion of learning, which affects the learning environment that teachers create (Bandura, 1993). It means self-efficacy induces motivation or pro-social motivation to help others at learning. Based on SCT, we assume that a self-efficient person may have higher levels of pro-sociality towards others. As self-efficacy and pro-social motivation bring positive results towards OCB, the relationship between self-efficacy and OCB through pro-social motivation has not been thoroughly discussed in earlier studies. We argue that the intensity of self-efficacy will determine the pro-social motivation levels and their subsequent effect on OCB.

\section{Incivility as a Moderator}

Incivility refers to "negative behavior with vague intent to harm the object resulting in violation of workstation norms and mutual respect" (Andersson \& Pearson, 1999, p. 457). According to past studies, more than seventy percent of people confess that they face uncivil behaviors while at work (Cortina et al., 2001; Cortina et al., 2002, 2008), arising from supervisors, colleagues, and clients (Schilpzand, De Pater, \& Erez, 2016). Over time these behaviors increase (Arasli et al., 2018) and now hovering serious concerns for organizations. These uncivil behaviors do damage the functional abilities of employees and fostering low performance. The negative impact of incivility on organizational commitment and job satisfaction has been reported in several studies (Lim \& Teo, 2009; Reio \& Ghosh, 2009). Furthermore, the supervisor related incivility that catalyst employee withdrawal behaviors (Raza, Ahmed, Zubair, Moueed, 2019; Sliter, Sliter, \& Jex, 2012). At the same time, incivility by coworkers has shown an increase in problems related to health (Kobayashi, Kaneyoshi, Yokota, \& Kawakami, 2008; Whitaker, 2001).

In academics, uncivil behaviors are common between nursing faculty and administrators (Southern, 2008), and incivility widespread can be seen where low decision-making power exists (DeMarco, Fawcett, \& Mazzawi, 2017). As per the study conducted by Reio and Reio (2011), eighty-five percent of the K-12 teachers experienced incivility from their colleagues, and seventy-one percent of teachers experienced workplace incivility from supervisors. Furthermore, past research shows that workplace incivility lowers employees' intrinsic motivation by increasing their emotional exhaustion (Hur et al., 2016).

De Clercq, Haq, and Azeem (2018), also revealed a link between self-efficacy and performance of job mediated by job-associated anxiety and the moderating role of workplace incivility. According to SCT, self-efficacy affects a person's behavior with a direct relationship, 
and the influence of negative actions hampers the direct positive relationship. In short, incivility influences motivation levels and the performance of employees; therefore, we propose that selfefficacy positively affects pro-social motivation. Still, workplace incivility influences prosocial motivation, which in turn affects the OCB.

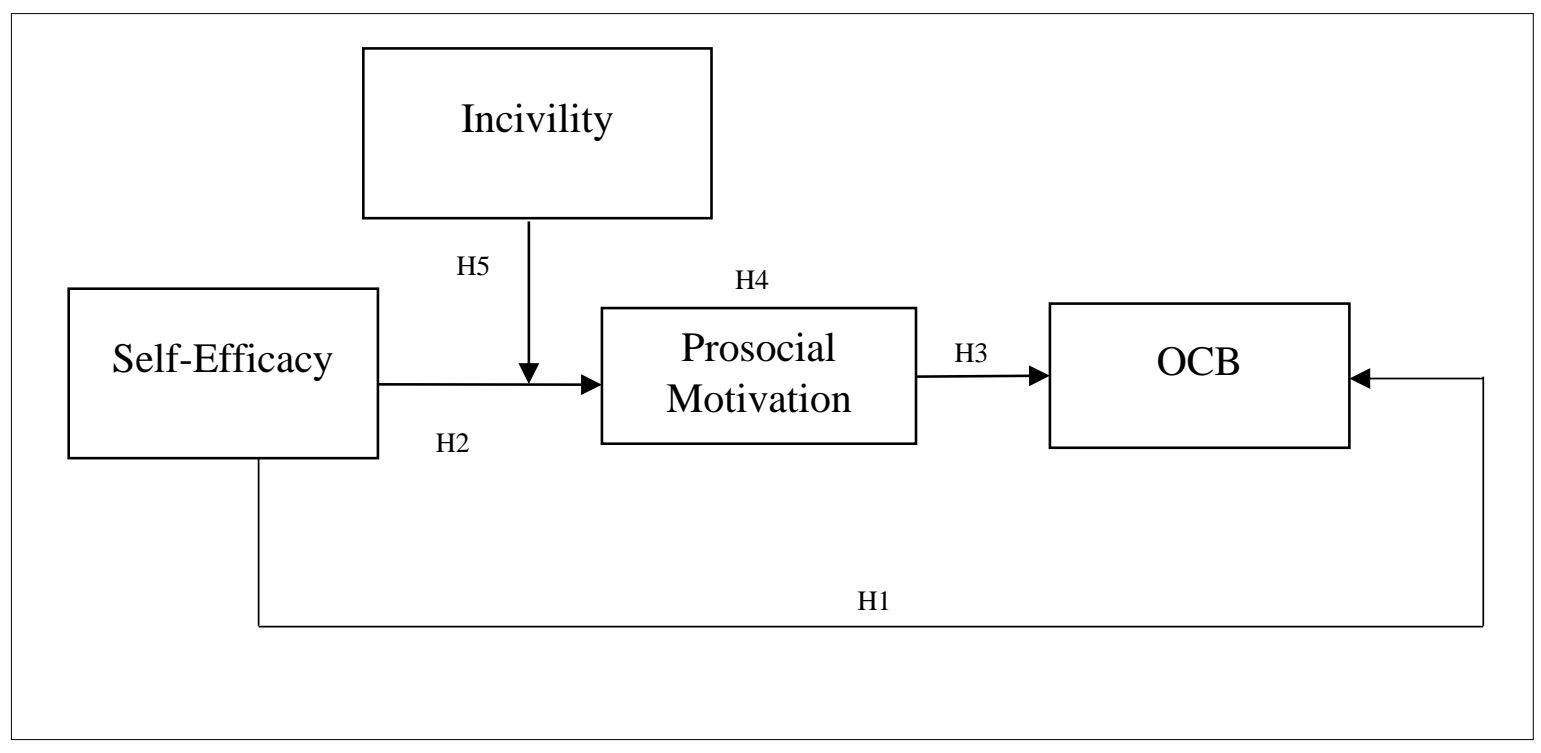

Figure 1. Conceptual framework.

\section{Research Question and Research Objectives}

The research questions of this study are:

Does teachers' self-efficacy have an impact on OCB?

Does pro-social motivation mediate the relationship between self-efficacy and OCB?

Does incivility moderate the relationship between teacher-related self-efficacy and pro-social motivation?

The hypotheses of the study are:

$\mathrm{H}_{1}$ : There is a positive impact of self-efficacy on organizational citizenship behavior.

$\mathrm{H}_{2}$ : Self-efficacy is positively related to pro-social motivation.

$\mathrm{H}_{3}$ : Pro-social motivation is positively related to OCB.

$\mathrm{H}_{4}$ : Pro-social motivation serves as a mediator between self-efficacy and OCB.

$\mathrm{H}_{5}$ : The incivility moderates the relationship between self-efficacy and pro-social motivation; such that incivility is high, the relationship will be weaker and vice versa.

\section{Methodology}

\section{Participants and Procedure}

This study is conducted in different educational institutes that have branches all over Pakistan. Participants (teachers) for the survey have been voluntarily invited by visiting different educational institutions. Therefore, the confidentiality of employees' (teachers) participation was assured. For that purpose, we first invited 51 undergraduate students to participate in the study. Out of 51 students, 48 students were agreed to participate in this study. As an incentive, full assignment marks were given to participating students. We gave instructions to students to go randomly to 48 different educational institutions and ask employees (teachers) to fill out 
questionnaires three times. In the first phase of data collection (Time 1), employees (teachers) were asked to respond to their intensities about self-efficacy and incivility along with their demographic details. In the second time phase (Time 2), two weeks later than Time 1, teachers responded about their pro-social motivation levels and the nomination of their best friend at work (colleague name). In the third phase of time (Time 3), exactly two weeks later than Time 2, data were collected from the nominated colleagues of the participant employees (teachers) who were participated in Time 1 and Time 2. The nominated colleagues responded about the levels of OCB of their coworkers (teachers who responded in Time 1 and Time 2). All the teachers and their colleagues filled paper-and-pencil surveys in the absence of each other.

At the start, questionnaires were delivered to 443 participants (teachers) during office hours, with 412 teachers responded to the first questionnaire (response rate was 93.0\%). Among them, 379 teachers completed the second questionnaire (response rate was 92.0\%). Then, students reached out to all nominated colleagues of these 379 teachers, and questionnaires were delivered to the 379 nominated colleagues. Out of 379 nominated colleagues, 338 nominated colleagues responded third survey (response rate was 89.1\%). Furthermore, by ensuring the recommendations of Meade and Craig (2012), we omitted 37 questionnaires filled by nominated colleagues identified as careless responses (i.e., use of the same scale anchor point for response). Hence, the final sample consists of 301 participant teachers.

\section{Measures}

Self-Efficacy. Self-Efficacy was measured at Time 1, using the eight-item scale developed by Chen, Gully, and Eden (2001). This eight-item measure comprises items such as, "I will be able to achieve most of the goals that I have set for myself" and "Compare to other people, I can do most tasks very well." Participants responded on a 5-point Likert-type scale ("1 = strongly disagree", " $5=$ strongly agree"). The internal consistency of this measure in our study is .81.

Incivility. We used an eight-item scale developed by Cortina et al (2001) to measure workplace incivility faced by employees from their supervisors or coworkers at Time 1 , consisting of items like "Put you down or condescending to you?" and "Made unwanted attempts to draw you into a discussion of personal matters?". Participants rated their responses on a five-point Likert-type scale ("1 = strongly disagree", "5 = strongly agree"). The Cronbach's alpha coefficient for this measure in our study is .83.

Pro-social motivation. Participants responded to their pro-social motivation levels at Time 2 by completing the scale developed by Grant and Sumanth (2009). This scale starts with the question, "I get energized by working on tasks that have the potential to benefit others," with other items including "I prefer to work on tasks that allow me to have a positive impact on others" and "I do my best when I'm working on a task that contributes to the well-being of others." The answers from participants were documented on a 5-point Likert-type scale ("1 = strongly disagree", " $5=$ strongly agree") having internal consistency $(\alpha=.79)$.

Organizational Citizenship Behavior (OCB). Participants (nominated colleagues) completed the OCBO scale developed by Lee and Allen (2002) to rate the levels of OCB of their fellow teachers (participants of Time 1 and Time 2) directed towards the organization. The first item of this scale is "Attend functions that are not required, but that help the organizational image," and several other items include "Take action to protect the organization from potential problems" and "Offer ideas to improve the functioning of the organization." Respondents' 
feedback was noted on a five-point Likert-type scale ("1 = Never", "5 = Always"). Cronbach's alpha for this measure in our study is .78.

\section{Control Variables}

We controlled some demographic variables for their impact on pro-social motivation and organizational citizenship behavior. Control variables included the gender of participants as past research referred to differences in gender in pro-sociality (Eagly \& Crowley, 1986). In addition, the age of the participants has been included in the control variables due to the study conducted by Omoto, Snyder, and Martino (2000), suggesting older people are more pro-social than younger people. The participant's designation has also been controlled because of its association using the degree of authority an individual possesses at a job (French \& Raven, 1959), consequently connected in the direction of pro-social abilities (Tost, Wade-Benzoni, \& Johnson, 2015). Finally, according to Dyne, Graham, and Dienesch (1994), pro-social behavior is associated with the amount of stay within the organization. Therefore, we included participant tenure in an organization in control variables.

\section{Results}

As per Table 1, the participant teachers responded at Time period 1 and Time period 2 (male = $61.5 \%$; married $=48.5 \%$; average age $=32.0$ years with $S D=9.7$ years; average years of education received $=16.3$ years with $S D=1.5$ years; average years of tenure in organization = 4.9 years with $S D=5.1$ years). The mean results of self-efficacy (SE) and OCB are more than prosocial motivation (PSM). The correlation between self-efficacy and OCB is higher than the positive correlation between self-efficacy and prosocial motivation. The standard deviation (SD) for prosocial motivation is .918 , greater among all other constructs. This means that teachers' prosocial motivation is volatile across different organizations due to certain working environments and incivility levels. The results also reported the negative correlation between incivility (INCV) and OCB.

\section{Table 1}

Descriptive Statistics along with Correlations (bivariate)

\begin{tabular}{|c|c|c|c|c|c|c|c|c|c|c|}
\hline & & 1 & 2 & 3 & 4 & 5 & 6 & 7 & $M$ & $S D$ \\
\hline 1 & SE & $(.81)$ & & & & & & & 4.17 & 0.37 \\
\hline 2 & INCV & .03 & $(.83)$ & & & & & & 4.22 & 0.56 \\
\hline 3 & PSM & $.27^{* *}$ & .05 & $(.79)$ & & & & & 3.97 & 0.91 \\
\hline 4 & OCB & $.65^{* *}$ & $-.13^{*}$ & .06 & $(.78)$ & & & & 4.32 & 0.40 \\
\hline 5 & Age_T1 (Years) & -.10 & .11 & .03 & $-.12^{*}$ & & & & 32.07 & 9.75 \\
\hline 6 & Tenure_T1 (Years) & -.05 & .10 & .04 & -.05 & $.83^{* *}$ & & & 4.93 & 5.14 \\
\hline 7 & Age_T2 (Years) & -.10 & .07 & .04 & $-.16^{* * *}$ & $.74^{* *}$ & $.61^{* *}$ & & 32.37 & 9.46 \\
\hline
\end{tabular}

Note. Values in parentheses represent Cronbach's alphas. $\mathrm{N}=301$

*Correlation is significant at the 0.05 level (2-tailed).

$* *$ Correlation is significant at the 0.01 level (2-tailed).

"IBM SPSS Statistics 22.0" and "SPSS Amos 22" were used for statistical analyses. Multiple confirmatory factor analyses (CFA) have been conducted to check the dimensionality of the four factors comprising self-efficacy, incivility, pro-social motivation, and OCB. Results exhibited that 4 -factor model represents better picture of data $\left(\chi^{2} / \mathrm{df}=1.69, \mathrm{CFI}=.94, \mathrm{TLI}=\right.$ $.93, \mathrm{GFI}=.89, \mathrm{RMSEA}=.48$ ), which is better than all additional models (i.e., 1-factor, 2-factor and 3 -factor models). The results of the four different models are presented in Table 2. 
Table 2

The Results of Multiple CFA

\begin{tabular}{lccccccc}
\hline Variables & $\chi^{2}$ & $d f$ & $\chi^{2} / d f$ & CFI & TLI & GFI & RMSEA \\
\hline (SE, INCV, PSM, OCB) $^{\text {1-factor model }}$ & & & & & & & \\
2-factor model $^{\mathrm{b}}$ & 1683.09 & 275 & 6.12 & .55 & .51 & .62 & .13 \\
3-factor model $^{\mathrm{c}}$ & 1570.50 & 274 & 5.73 & .59 & .55 & .63 & .12 \\
4-factor model $^{\mathrm{d}}$ & 1026.58 & 272 & 3.77 & .76 & .73 & .73 & .09 \\
\hline & 453.45 & 268 & 1.69 & .94 & .93 & .89 & .04 \\
\hline
\end{tabular}

a. SE, INCV, PSM, and OCB all combined as one-factor

b. SE and INCV in a single factor, PSM and OCB in a single factor

c. SE and INCV in a single factor, PSM in a single factor, OCB in a single factor

d. SE in a single factor, INCV in a single factor, PSM in a single factor, OCB in the single factor

Furthermore, we also test the moderation mediation model using "PROCESS macro" (Hayes, 2013). Five thousand samples were generated to study the indirect effect (conditional) of self-efficacy over OCB through pro-social motivation at diverse levels of incivility. To test the hypotheses, 5000 samples were set as bootstrapping. Moderated mediation results indicate self-efficacy is positively related to pro-social motivation $(b=2.931, p=0.10)$ when the dependent variable is pro-social motivation (mediator variable model). The interaction term of self-efficacy and incivility is significant and negatively associated $(B=-.53, p=.04)$ when prosocial motivation is considered a dependent variable in a model. In a model where OCB is taken as a dependent variable, pro-social motivation is negatively associated with OCB $(B=-.05, p$ $=.01)$, significant at $p<.05$. In contrast, self-efficacy is significant and positively related to OCB $(B=.72, p=.000, p<.01)$. The indirect effects (conditional) of self-efficacy on OCB at different levels of incivility are presented in Table 3, indicating self-efficacy is weakly associated with OCB through pro-social motivation when incivility levels are low. With the increase in the levels of incivility, a strong association between self-efficacy and OCB through pro-social motivation can be seen, indicating a negative relation of pro-social motivation towards OCB. The moderated mediation index shows significant result $(B=.02,90 \% \mathrm{BCa} \mathrm{CI}$ $=.007-.06)$.

Table 3

Indirect Effect (conditional) of Self-efficacy over OCB through Pro-social Motivation with Incivility as Moderator $(N=301$, Bootstrapping $=5000$ Samples, Unstandardized Coefficients $)$

\begin{tabular}{|c|c|c|c|c|}
\hline Predictor & $B$ & $p$ & $\mathrm{SE}$ & $90 \% \mathrm{SE}$ \\
\hline \multicolumn{5}{|c|}{$\mathrm{DV}=\mathrm{PSM}$ (Mediator variable model) } \\
\hline Self-efficacy & 2.93 & .01 & 1.13 & $1.06-4.80$ \\
\hline INCV & 2.29 & .04 & 1.11 & $0.46-4.13$ \\
\hline Self-efficacy $\times$ INCV & -0.53 & .04 & 0.26 & $-0.97--0.09$ \\
\hline \multicolumn{5}{|c|}{$\mathrm{DV}=\mathrm{OCB}$ (Dependent variable model) } \\
\hline PSM & -0.05 & .01 & 0.02 & $-0.08--0.01$ \\
\hline Self-efficacy & 0.72 & .00 & 0.04 & $0.65-0.80$ \\
\hline \multicolumn{5}{|c|}{$\begin{array}{l}\text { Indirect effects (conditional) of self-efficacy over OCB } \\
\text { at various levels of INCV (moderator) }\end{array}$} \\
\hline Values of moderator & $B$ & & Boot SE & $90 \% \mathrm{BCa} \mathrm{CI}$ \\
\hline $10^{\text {th }}$ percentile & -.05 & & .02 & $-.11--.02$ \\
\hline $25^{\text {th }}$ percentile & -.03 & & .01 & $-.06--.01$ \\
\hline $50^{\text {th }}$ percentile & -.03 & & .01 & $-.05--.01$ \\
\hline $75^{\text {th }}$ percentile & -.02 & & .01 & $-.05--.00$ \\
\hline $90^{\text {th }}$ percentile & -.01 & & .01 & $-.04--.00$ \\
\hline \multicolumn{5}{|c|}{ Index of moderated mediation } \\
\hline PSM (mediator) & .02 & & .01 & $.00-.06$ \\
\hline
\end{tabular}

Note. INCV=Incivility, PSM=Prosocial motivation, $\mathrm{OCB}=$ Organizational citizenship behavior 
Figure 2 shows that teachers with higher self-efficacy demonstrate OCB better than the teachers with low self-efficacy, even there are higher levels of incivility in the organization.

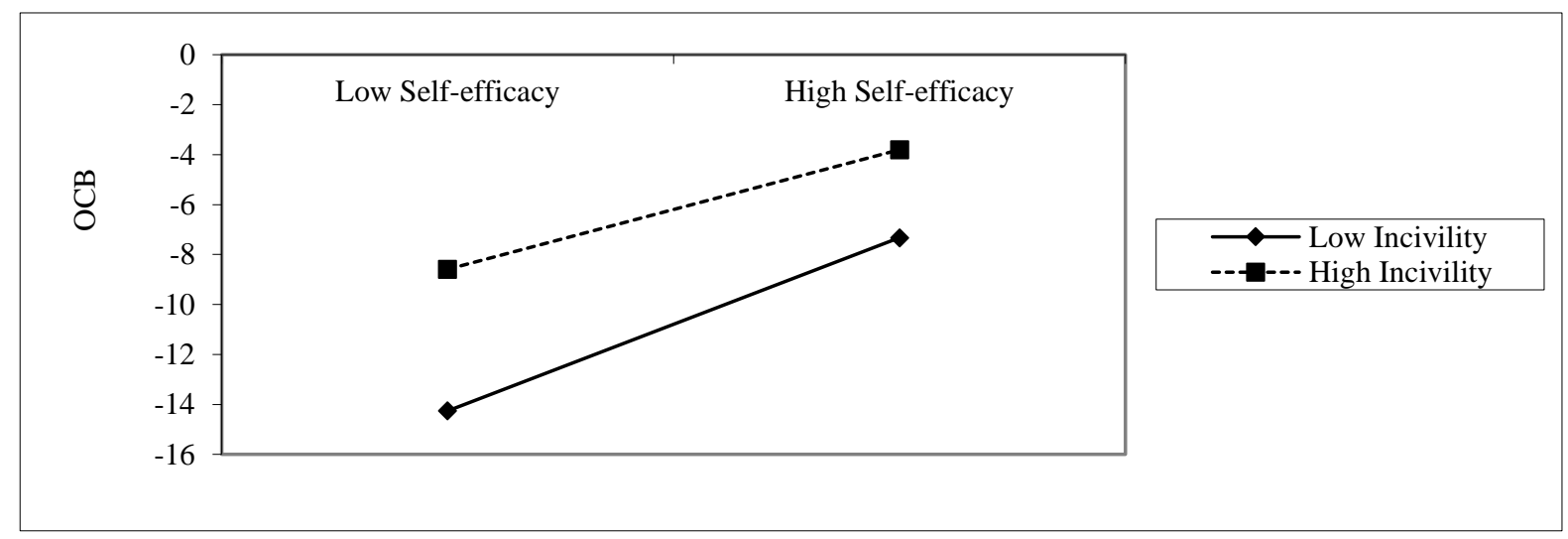

Figure 2. Moderation graph.

\section{Discussion}

The results demonstrate evidence that the link between self-efficacy and OCB through prosocial motivation is moderated by incivility. As per results, self-efficacy is directly related to pro-social motivation. Higher self-efficacy levels lead to higher levels of pro-social motivation, consistent with our hypothesis $\left(\mathrm{H}_{1}\right)$ and in line with the studies of (Bogler \& Somech, 2004; Paramasivam, 2015; Raza \& Ahmed, 2020; Ringgasa, 2017). Also, from the results, selfefficacy serves as an antecedent to pro-social motivation. Moreover, self-efficacy and prosocial motivation have a positive relationship $\left(\mathrm{H}_{2}\right)$. Results show higher levels of teacher selfefficacy leads to higher levels of prosocial motivation. Hence, this result supports our hypothesis $\left(\mathrm{H}_{2}\right)$. The interaction term for self-efficacy and incivility negatively impacts prosocial motivation. As shown in Table 3, when incivility levels are low, self-efficacy on OCB via pro-social motivation is weaker, but as incivility increases, this effect became stronger. When incivility level increases, individuals' pro-social motivation tends to reduce, negatively associated with OCB.

Furthermore, hypothesis $\left(\mathrm{H}_{3}\right)$ is not supported contrary to the study of Lebel and Patil (2018), which shows workers who are motivated on a pro-social basis maintain their tendency to help others. As per results, pro-social motivation is negatively associated with OCB due to predominant incivility in the organization. The pro-sociality of individuals decreases if they experience incivility. Thus, individuals are not willing to perform OCB towards the organization. However, the direct relationship of self-efficacy over OCB is positive and in line with some studies (Bogler \& Somech, 2004; Judge \& Bono, 2001; Judge et al., 1998; Paramasivam, 2015).

Moreover, results supported hypothesis $\left(\mathrm{H}_{4}\right)$ that pro-social motivation acts as a mediator between self-efficacy and OCB, which indicates that self-efficacy (individual-level personal factor) is more important and influential than organizational factors in influencing pro-social motivation and OCB behaviors. It is also evident that incivility moderates the relationship between self-efficacy and pro-social motivation, which aligns with our hypothesis $\left(\mathrm{H}_{5}\right)$. Hence, results also supported the hypothesis $\left(\mathrm{H}_{5}\right)$ and validated the results of the studies conducted by Reio and Reio (2011) that teachers face incivility from colleagues and supervisors. 


\section{Practical and Theoretical Contribution}

This study has both practical and theoretical contributions. First, there is a need to promote and arrange training sessions for enhancing teachers' self-efficacy, which enhances the pro-social motivation and OCB for the development and achievement of students. Second, the administrators should encourage employee initiative, promoting risk-taking, openness to newer ideas, innovation, and leadership. This kind of culture will increase the institute's sense of selfefficacy and effectiveness in the long run. Third, the OCB behavior has been studied in a different context, but few studies underlie the antecedents of OCB behavior in academic institutions' context. So, the findings of this study are unique, based on its nature and scope.

This study results in a twofold contribution towards the existing body of knowledge. First, it shows that self-efficacy acts as a catalyst in enhancing the pro-social motivation of individuals contrary to previous studies, e.g., the influence of self-efficacy on work-related employee motivation (Cherian \& Jacob, 2013), and further, it influences academic motivation (Schunk, $\&$ Dale, 1991). Thus, self-efficacy serves as an antecedent to pro-social motivation, which has, to our best knowledge, not been discussed earlier in the academic organization setting. Second, this study contributes to the Social Cognitive Theory so that self-efficacy promotes pro-social motivation, leading to OCB. However, earlier studies showed the only direct impact of selfefficacy over OCB (Paramasivam, 2015; Ringgasa, 2017).

\section{Limitations and Future Directions}

The first limitation of this study is the participation of students in a response collection, even though the earlier study proposes that there is not a significant difference between the samples collected by students and others (Wheeler, Shanine, Leon, \& Whitman, 2014). Therefore, students were given credit against an assignment that wishes to participate in this research study. In addition, those students who were not a part of this study were given additional assignments. The second limitation of this study is incivility was taken as a first stage moderator to assess self-efficacy and pro-social motivation. Future studies shall take other negative constructs such as mobbing, bullying, and harassment as a moderator to assess the relationship between self-efficacy and pro-social motivation. The third limitation of this study is the academic organizational context. Data have been collected from teachers only to assess the moderated mediation analysis.

Future studies can incorporate survey data from different organizations and industries to find new avenues to the understudied relationship of self-efficacy and OCB via pro-social motivation. Future studies should also use multiple location response data to validate the present study, as the data collection in this study is within the boundaries of Lahore, Pakistan. Furthermore, studies in the future should also consider large data samples from different cultural backgrounds.

\section{Conclusion}

In a nutshell, this study demonstrates the positive direct impact of self-efficacy over OCB within academic settings. Results showed that self-efficacy is directly proportional to pro-social motivation, and incivility impacts pro-social motivation negatively. The study also indicates that teachers' self-efficacy boosts their desire to help others but not the organization. The inability to demonstrate OCB is the presence of incivility within the academic organization. As teachers experience incivility from their colleagues and other academic and non-academic staff, 
their pro-social motivation towards the organization declines. They are unwilling to cooperate with the organization, i.e., lack of interest in organizational developments and lack of participation in the organization functioning of the institution, and employee loyalty issues.

\section{References}

Abid, G., Sajjad, I., Elahi, N. S., Farooqi, S., \& Nisar, A. (2018). The influence of pro-social motivation and civility on work engagement: The mediating role of thriving at work. Cogent Business and Management, 5(1), 1-19. https://doi.org/10.1080/23311975.2018.1493712

Alola, U. V., Avci, T., \& Ozturen, A. (2018). Organization sustainability through human resource capital: The impacts of supervisor incivility and self-efficacy. Sustainability, 10(8), 1-16. https://doi.org/10.3390/su10082610

Andersson, L. M., \& Pearson, C. M. (1999). Tit for tat? the spiraling effect of incivility in the workplace. Academy of Management Review, 24(3), 452-471. https://doi.org/10.5465/AMR.1999.2202131

Arasli, H., Hejraty Namin, B., \& Abubakar, A. M. (2018). Workplace incivility as a moderator of the relationships between polychronicity and job outcomes. International Journal of Contemporary Hospitality Management, 30(3), 1245-1272. https://doi.org/10.1108/IJCHM-12-2016-0655

Arieli, S., Grant, A. M., \& Sagiv, L. (2014). Convincing yourself to care about others: An intervention for enhancing benevolence values. Journal of Personality, 82(1), 15-24. https://doi.org/10.1111/jopy.12029

Asandimitra, N., \& Kautsar, A. (2019). The influence of financial information, financial self-efficacy, and emotional intelligence to financial management behavior of female lecturer. Humanities and Social Sciences Reviews, 7(6), 11121124. https://doi.org/10.18510/hssr.2019.76160

Bandura, A. (1993). Perceived self-efficacy in cognitive development and functioning. Educational Psychologist, 28(2), 117148. https://doi.org/10.1207/s15326985ep2802_3

Bandura, A. (1997). Self-efficacy: The exercise of control. American Journal of Health Promotion, 149(3), 8-10. https://doi.org/10.1177/0957154X9400501708

Bogler, R., \& Somech, A. (2004). Influence of teacher empowerment on teachers' organizational commitment, professional commitment and organizational citizenship behavior in schools. Teaching and Teacher Education, 20(3), 277-289. https://doi.org/10.1016/j.tate.2004.02.003

Brouwers, A., \& Tomic, W. (2000). A longitudinal study of teacher burnout and perceived self-efficacy in classroom management. Teaching and Teacher Education, 16(2), 239-253. https://doi.org/10.1016/S0742-051X(99)00057-8

Caprara, G. V., Barbaranelli, C., Steca, P., \& Malone, P. S. (2006). Teachers' self-efficacy beliefs as determinants of job satisfaction and students' academic achievement: A study at the school level. Journal of School Psychology, 44(6), 473490. https://doi.org/10.1016/j.jsp.2006.09.001

Castanheira, F., Chambel, M. J., Lopes, S., \& Oliveira-Cruz, F. (2016). Relational job characteristics and work engagement: Mediation by pro-social motivation. Military Psychology, 28(4), 226-240. https://doi.org/10.1037/mil0000116

Chen, G., Gully, S. M., \& Eden, D. (2001). Validation of a new general self-efficacy scale. Organizational Research Methods, 4(1), 62-83. https://doi.org/10.1177/109442810141004

Cherian, J., \& Jacob, J. (2013). Impact of self-efficacy on motivation and performance of employees. International Journal of Business and Management, 8(14), 80-88. https://doi.org/10.5539/ijbm.v8n14p80

Cortina, L. M. (2008). Unseen injustice: Incivility as modern discrimination in organizations. Academy of Management Review, 33(1), 55-75. https://doi.org/10.5465/AMR.2008.27745097

Cortina, L. M., Lonsway, K. A., Magley, V. J., Freeman, L. V., Collinsworth, L. L., Hunter, M., \& Fitzgerald, L. F. (2002). What's gender got to do with it? Incivility in the federal courts. In Law and social inquiry (Vol. 27, pp. 235-270). https://doi.org/10.1111/j.1747-4469.2002.tb00804.x

Cortina, L. M., Magley, V. J., Williams, J. H., \& Langhout, R. D. (2001). Incivility in the workplace: Incidence and impact. Journal of Occupational Health Psychology, 6(1), 64-80. https://doi.org/10.1037/1076-8998.6.1.64

De Clercq, D., Haq, I. U., \& Azeem, M. U. (2018). Self-efficacy to spur job performance: Roles of job-related anxiety and perceived workplace incivility. Management Decision, 56(4), 891-907. https://doi.org/10.1108/MD-03-2017-0187

DeMarco, R. F., Fawcett, J., \& Mazzawi, J. (2017). Covert incivility: Challenges as a challenge in the nursing academic workplace. Journal of Professional Nursing. https://doi.org/10.1016/j.profnurs.2017.10.001 
Dyne, L. Van, Graham, J. W., \& Dienesch, R. M. (1994). Organisational citizenship behaviour: Construct redefinition, measurement, and validation. The Academy of Management Journal, 37(4), 765-802.

Eagly, A. H., \& Crowley, M. (1986). Gender and helping behavior. A meta-analytic review of the social psychological literature. Psychological Bulletin 100(3), 283-308. https://doi.org/10.1037/0033-2909.100.3.283

French, J. R. P., Jr., \& Raven, B. (1959). The bases of social power. In D. Cartwright (Ed.), Studies in social power (pp. 150167). Univer. Michigan.

Goddard, R. D., Hoy, W. K., \& Hoy, A. W. (2004). Collective efficacy beliefs: Theoretical developments, empirical evidence, and future directions. Educational Researcher, 33(3), 3-13. https://doi.org/10.3102/0013189X033003003

Goldhaber, D. (2002). The mystery of good teaching. Education Next, 2(1), 50-55. Retrieved from http://educationnext.org/200121/index.html\%5Cnhttp://find.galegroup.com/itx/infomark.do?\&contentSet=IACDocumen ts\&type=retrieve \&tabID=T002\&prodId=EAIM\&docId=A87209056\&source=gale\&srcprod=EAIM\&userGroupName= wash_eai\&version $=1.0$

Grant, A. M., \& Berg, J. M. (2012). Pro-social motivation at work: When, why, and how making a difference makes a difference. In the Oxford Handbook of Positive Organizational Scholarship. https://doi.org/10.1093/oxfordhb/9780199734610.013.0003

Grant, A. M., Campbell, E. M., Chen, G., Cottone, K., Lapedis, D., \& Lee, K. (2007). Impact and the art of motivation maintenance: The effects of contact with beneficiaries on persistence behavior. Organizational Behavior and Human Decision Processes, 103(1), 53-67. https://doi.org/10.1016/j.obhdp.2006.05.004

Grant, A. M., \& Mayer, D. M. (2009). Good soldiers and good actors: Pro-social and impression management motives as interactive predictors of affiliative citizenship behaviors. Journal of Applied Psychology, 94(4), 900-912. https://doi.org/10.1037/a0013770

Grant, A. M., \& Sumanth, J. J. (2009). Mission possible? The performance of prosocially motivated employees depends on manager trustworthiness. Journal of Applied Psychology, 94(4), 927-944. https://doi.org/10.1037/a0014391

Guskey, T. R., \& Passaro, P. D. (1994). Teacher efficacy: A study of construct dimensions. American Educational Research Journal, 31(3), 627-643. https://doi.org/10.3102/00028312031003627

Hayes, A. F. (2013). Introduction to meditaion, moderation, and conditional process analysis: A regression-based approach. Guilford Press. https://doi.org/10.5539/ass.v11n9p207

Hur, W. M., Moon, T., \& Jun, J. K. (2016). The effect of workplace incivility on service employee creativity: The mediating role of emotional exhaustion and intrinsic motivation. Journal of Services Marketing, 30(3), 302-315. https://doi.org/10.1108/JSM-10-2014-0342

Judge, T. A., \& Bono, J. E. (2001). Relationship of core self-evaluations traits - Self-esteem, generalized self-efficacy, locus of control, and emotional stability-with job satisfaction and job performance: A meta-analysis, 86(1), 80-92. Journal of Applied Psychology. https://doi.org/10.1037/0021-9010.86.1.80

Judge, T. A., Locke, E. A., Durham, C. C., \& Kluger, A. N. (1998). Dispositional effects on job and life satisfaction: The role of core evaluations. Journal of Applied Psychology, 83(1), 17-34. https://doi.org/10.1088/0256-307X/24/3/032

Kobayashi, Y., Kaneyoshi, A., Yokota, A., \& Kawakami, N. (2008). Effects of a worker participatory program for improving work environments on job stressors and mental health among workers: A controlled trial. Journal of Occupational Health, 50(6), 455-470. https://doi.org/10.1539/joh.L7166

Lane, J., Lane, A. M., \& Kyprianou, A. (2004). Self-efficacy, self-esteem and their impact on academic performance. Social Behavior and Personality: An International Journal, 32(3), 247-256. https://doi.org/10.2224/sbp.2004.32.3.247

Lebel, R. D., \& Patil, S. V. (2018). Proactivity despite discouraging supervisors: The powerful role of pro-social motivation. Journal of Applied Psychology, 103(7), 724-737. https://doi.org/10.1037/ap10000301

Lee, K., \& Allen, N. J. (2002). Organizational citizenship behavior and workplace deviance: The role of affect and cognitions. Journal of Applied Psychology, 87(1), 131-142. https://doi.org/10.1037/0021-9010.87.1.131

Lim, V. K. G., \& Teo, T. S. H. (2009). Mind your E-manners: Impact of cyber incivility on employees' work attitude and behavior. Information and Management, 46(8), 419-425. https://doi.org/10.1016/j.im.2009.06.006

Lin, S. C., Schaumberg, R. L., \& Reich, T. (2016). Sidestepping the rock and the hard place: The private avoidance of prosocial requests. Journal of Experimental Social Psychology, 64, 35-40. https://doi.org/10.1016/j.jesp.2016.01.011

Meade, A. W., \& Craig, S. B. (2012). Identifying careless responses in survey data. Psychological Methods, 17(3), 437-455. https://doi.org/10.1037/a0028085

Nowakowska, I., Rasińska, R., \& Głowacka, M. D. (2016). The influence of factors of work environment and burnout syndrome on self-efficacy of medical staff. Annals of Agricultural and Environmental Medicine, 23(2), 304-309. https://doi.org/10.5604/12321966.1203895

Omoto, A. M., Snyder, M., \& Martino, S. C. (2000). Volunteerism and the life course: Investigating age-related agendas for action. Basic and Applied Social Psychology, 22(3), 181-197. https://doi.org/10.1207/S15324834BASP2203 
Oplatka, I. (2009). Organizational citizenship behavior in teaching: The consequences for teachers, pupils, and the school. International Journal of Educational Management, 23(5), 375-389. https://doi.org/10.1108/09513540910970476

Organ, D. W., \& Ryan, K. (1995). A meta-analytic review of attitudinal and dispositional predictors of organizational citizenship behavior. Personnel Psychology, 48(4), 775-802. https://doi.org/10.1111/j.1744-6570.1995.tb01781.x

Paramasivam, G. M. (2015). Role of self-efficacy and family supportive organizational perceptions in teachers' organizational citizenship behaviour: A study on engineering college teachers in India. Asian Education and Development Studies, 4(4), 394-408. https://doi.org/10.1108/AEDS-01-2015-0001

Podsakoff, P. M., Ahearne, M., \& MacKenzie, S. B. (1997). Organizational citizenship behavior and the quantity and quality of work group performance. Journal of Applied Psychology, 82(2), 262-270. https://doi.org/10.1037/0021-9010.82.2.262

Raza, B., Ahmed, A. (2020). Linking workplace deviance and managerial coaching: The mediating role of thriving at work. Iranian Journal of Management Studies, 13(3), 467-494.

Raza, B., Ahmed, A., Zubair, S., Moueed, A. (2019). Linking workplace deviance and abusive supervision: Moderating role of psychological capital. International Journal of Organizational Leadership, 8(1), 95-111.

Reio, T. G., \& Ghosh, R. (2009). Antecedents and outcomes of workplace incivility: Implications for human resource development research and practice. Human Resource Development Quarterly, 20(3), $237-264$. https://doi.org/10.1002/hrdq.20020

Reio, T. G., \& Reio, S. M. (2011). Workplace incivility in schools. International Journal of Adult Vocational Education and Technology, 2(1), 23-35. https://doi.org/10.4018/javet.2011010103

Riadi, S. S., Hendryadi, \& Tricahyadinata, I. (2019). Workplace incivility, self-efficacy, and turnover intention relationship model: A multi-group analysis. Russian Journal of Agricultural and Socio-Economic Sciences, 85(1), 358-368. https://doi.org/10.18551/rjoas.2019-01.44

Ringgasa, L. (2017). The effect of self-efficacy on organizational citizenship behavior (ocb) employees of institut agama islam negeri kendari. Langkawi ISSN, 3(2), 2460-2280.

Rioux, S. M., \& Penner, L. A. (2001). The causes of organizational citizenship behavior: A motivational analysis. Journal of Applied Psychology, 86(6), 1306-1314. https://doi.org/10.1037/0021-9010.86.6.1306

Robbins, S. P. (2005). Principles of organizational behavior. International, Prentice Hall. Retrieved from http://wwwuser.gwdg.de/ uwuf/pdfdatei/orga/Chapt1.pdf

Ross, J. A. (1992). Teacher efficacy and the effects of coaching on student achievement. Canadian Journal of Education $/$ Revue Canadienne de L'éducation, 17(1), 51-65. https://doi.org/10.2307/1495395

Schilpzand, P., De Pater, I. E., \& Erez, A. (2016). Workplace incivility: A review of the literature and agenda for future research. Journal of Organizational Behavior, 37, S57-S88. https://doi.org/10.1002/job.1976

Schunk, D. H. (1991). Self-efficacy and academic motivation. Educational Psychologist, 26(3-4), $207-231$. https://doi.org/10.1177/0731121416629993

Schwarzer, R., \& Hallum, S. (2008). Perceived teacher self-efficacy as a predictor of job stress and burnout: Mediation analyses. Applied Psychology, 57(SUPPL. 1), 152-171. https://doi.org/10.1111/j.1464-0597.2008.00359.x

Sliter, M., Sliter, K., \& Jex, S. (2012). The employee as a punching bag: The effect of multiple sources of incivility on employee withdrawal behavior and sales performance. Journal of Organizational Behavior, 33(1), 121-139. https://doi.org/10.1002/job.767

Southern, K. (2008). Faculty incivility: The rise of the academic bully culture and what to do about it. International Journal of Educational Advancement, 8(3-4), 249-251. https://doi.org/10.1057/ijea.2009.12

Tost, L. P., Wade-Benzoni, K. A., \& Johnson, H. H. (2015). Noblesse oblige emerges (with time): Power enhances intergenerational beneficence. Organizational Behavior and Human Decision Processes, 128, 61-73. https://doi.org/10.1016/j.obhdp.2015.03.003

Tschannen-Moran, M., \& Hoy, A. W. (2001). Teacher efficacy: Capturing an elusive construct. Teaching and Teacher Education, 17(7), 783-805. https://doi.org/10.1016/S0742-051X(01)00036-1

Vancouver, J. B., \& Kendall, L. N. (2006). When self-efficacy negatively relates to motivation and performance in a learning context. Journal of Applied Psychology, 91(5), 1146-1153. https://doi.org/10.1037/0021-9010.91.5.1146

Wang, H., Hall, N. C., \& Rahimi, S. (2015). Self-efficacy and causal attributions in teachers: Effects on burnout, job satisfaction, illness, and quitting intentions. Teaching and Teacher Education, 47, 120-130. https://doi.org/10.1016/j.tate.2014.12.005

Wheeler, A. R., Shanine, K. K., Leon, M. R., \& Whitman, M. V. (2014). Student-recruited samples in organizational research: A review, analysis, and guidelines for future research. Journal of Occupational and Organizational Psychology, 87(1), 126. https://doi.org/10.1111/joop.12042 
Whitaker, S. C. (2001). The management of sickness absence. Occupational and Environmental Medicine, 420-424. https://doi.org/10.1136/oem.58.6.420

Yeşilyurt, E., Ulaş, A. H., \& Akan, D. (2016). Teacher self-efficacy, academic self-efficacy, and computer self-efficacy as predictors of attitude toward applying computer-supported education. Computers in Human Behavior, 64, 591-601. https://doi.org/10.1016/j.chb.2016.07.038

York-Barr, J., \& Duke, K. (2004). What do we know about teacher leadership? Findings from two decades of scholarship, 74(3), 255-316. Review of Educational Research. https://doi.org/10.3102/00346543074003255

Zee, M., Koomen, H. M. Y., Jellesma, F. C., Geerlings, J., \& de Jong, P. F. (2016). Inter- and intra-individual differences in teachers' self-efficacy: A multilevel factor exploration. Journal of School Psychology, 55, 39-56. https://doi.org/10.1016/j.jsp.2015.12.003

\section{Acknowledgements}

Not applicable.

\section{Disclosure Statement}

No potential conflict of interest was reported by the authors.

\section{Funding Acknowledgements}

Not applicable.

\section{Open Access}

The International Journal of Organizational Leadership publishes open access articles under the terms of the Creative Commons Attribution (CC BY) License, which permits use, distribution, and reproduction in any medium, provided the original work is properly cited. 